\title{
Effect of heat treatment on corrosion resistance of friction stir welded AA 2024 aluminum alloy
}

\author{
Prof. Dr. Muna K. Abbass ${ }^{1}$, Dr. Hani Aziz Ameen ${ }^{2}$ and Khairia Salman Hassan ${ }^{3}$ \\ ${ }^{1}$ Dept. of Production Eng. and Metallurgy, University of Technology, Baghdad, Iraq. \\ Email: mukeab2005@yahoo.com \\ ${ }^{2}$ Technical College - Baghdad - Iraq. E-mail:haniazizameen@yahoo.com \\ ${ }^{3}$ Institute of Technology - Baghdad / Mechanical Dept.-Iraq. \\ E-mail:almaden20002000@yahoo.com
}

\begin{abstract}
This work aims to study the effect of heat treatment on the corrosion resistance of friction stir welded joint of AA2024 aluminum alloy. The microstructure and corrosion behavior of the welds and base alloy were studied before and after age hardening heat treatment which includes solution heat treatment at $510^{\circ} \mathrm{C}$ and aging at $190^{\circ} \mathrm{C}$ for $3 \mathrm{hrs}$. The friction stir welding was carried out by using CNC milling machine at constant tool rotational speed of $(1000 \mathrm{rpm})$ and welding speed of $(20 \mathrm{~mm} / \mathrm{min})$. Corrosion current was found using potentiostatic polarization measurements of all samples in $3.5 \% \mathrm{NaCl}$ solution at a temperature of $30^{\circ} \mathrm{C}$. It was found that the corrosion rate of weld was higher than that of base alloy before age hardening treatment. Post weld aging treatment leads to increase the corrosion resistance of weld because of precipitation homogeneity occurring in the microstructures of various welding regions.
\end{abstract}

Keywords: Friction stir welding, Al-alloys, corrosion, heat treatment

\section{INTRODUCTION}

Friction stir welding (FSW) is a new solid state joining process that offers significant benefits over conventional joining processes. Invented by the welding Institute (TWI) in 1991. FSW uses a combination of frictional heating and compressive loading to join metal plates that are butted against each other and tightly clamped to the anvil of the machine (Maria Posada et al, 2003 and Sindo Kou,2003). Recently aluminum alloys have been used in automotive, shipbuilding and aircraft products, railway rolling stock industries and most likely others (www.esabna.com,2008), because they are light in weight, easy to machine and have relatively high tensile strength .Age hardening heat treatment (T4 or T6) is generally used for increasing the strength in heat treatable aluminum alloys of $(2000,6000$ and 7000 series ). In products of fusion welding processes such as (TIG) or (MIG), hot cracking often occurs without filler metals. These problems can by eliminated in FSW process (Sutton,2002). Beate Heinz and Birgit Skroyzki,2002 studied the effect of friction stir welding on the microstructure and mechanical properties of Al-alloy 6013-T4 and T6 tempered after applying a postweld heat treatment. Optical microscopy and TEM examination of the weld nugget region show that the strengthening precipitates present before welding in the T6 temper, were dissolved during welding in the nugget, while an overaged state with much larger precipitate size was established in the heat affected zone(HAZ). Microhardness measurements and tensile tests show that the HAZ is the weakest region of the weld. Venugopal et al,2004 studied microstructural and pitting corrosion properties of friction stir welded $7075 \mathrm{Al}$-alloy in $3.5 \% \mathrm{NaCl}$ solution. Corrosion resistance of weld metal has better than that of thermo-mechanically affected zone (TMAZ) and base metal. Friction stir welding of alloy 7075 resulted in fine recrystallized grains in a weld nugget which has been attributed to frictional heating and plastic flow. Cao and Kou,2005 studied FSW, gas metal arc welding (GMAW) of alloy 2219. GMAW was conducted to provide a bench mark for checking liquation in FSW of alloy 2219. The microstructure of the resultant welds was examined by both optical and SEM. It was found that in GMAW of alloy 2219, $\left(\mathrm{Al}_{2} \mathrm{Cu}\right)$ particles acted as in-situ micro sensors clearly in decanting the onset of liquation, and showed no evidence of induced liquation during FSW. Paglia and Buchheit,2008 applied short-term post-weld heat treatments, for some minutes at a temperature between 250 and $450^{\circ} \mathrm{C}$, i.e., similar to that during the welding. The treatment was carried out for friction stir welded aluminum alloy 7075-T651 
and 2219-T87. They concluded that such treatments modify the microstructure and reduce the corrosion of the welds. An increase in the corrosion resistance may also be reached by modifying the microchemistry during welding. Weifeng $\mathrm{Xu}$ and Jinhe Liu,2009 investigated the effect of welding parameters on the microstructure and pitting corrosion at different positions along the thickness of weld nugget zone in friction stir welded 2219-O aluminum alloy plate, using scanning electron microscopy (SEM), polarization experiment and electrochemical impedance tests (EIS). It was found that the material presents significant passivation and the top has best corrosion resistance compared to the bottom and base material. Ju Kang et al, 2010 investigated the surface corrosion behavior of an AA2024-T3 aluminum alloy sheet after friction stir welding by using an "in-situ observation" method. SEM observations showed that the density and degree of the pitting corrosion in the shoulder active zone were slightly larger compared to the other regions on the top surface. The origins of the pitting corrosion were in the regions between the $S$ phase particles and the adjacent aluminum base. The aim of present work is to study the effect of age hardening treatment on the microstructures and corrosion resistance of the AA2024 aluminum alloy welded by friction stir process.

\section{Experimental Work}

\section{Welding Process}

The base metal used in this work was $5 \mathrm{~mm}$ thick AA2024-T3 aluminum alloy plate, whose chemical composition is provided in Table1. The samples of $70 \mathrm{~mm} \times 100 \mathrm{~mm}$ were longitudinally butt welded using CNC milling machine (type Bridgeport). All similar welds of 2024-T3 aluminum alloy were performed using a welding tool made of medium carbon steel (St45). The welding tool is composed of shoulder of (20 $\mathrm{mm}$ diameter) and probe of $(5 \mathrm{~mm}$ diameter and $4.7 \mathrm{~mm}$ length). Welding procedure includes three steps:

1- Plunging step 2- Stirring and welding step 3Retracting of welding tool step

The welding tool is rotated at high speed and plunged into the joint line between two plates to be butt welded together (Zhili Feng et al,2003). This stirring action of the rotating tool yields a heavily deformed alloy. The frictional heat generated by the welding tool makes the surrounding material softer and allows the tool to move along the joint line. The softened material starts to flow around probe resulting in transferring of material from the leading edge of the tool to the side (Maria Posada et al,2003). In this study, the welding parameters such as tool rotation speed of (1000 rpm) and travel or welding speed of $(20 \mathrm{~mm} / \mathrm{min})$ are constants.

Table 1 Chemical composition analysis of 2024 T3 Al - alloy

\begin{tabular}{|c|c|c|c|c|c|c|c|c|}
\hline Elément & $\mathrm{Cu}$ & $\mathrm{Mn}$ & $\mathrm{Mg}$ & $\mathrm{Si}$ & $\mathrm{Fe}$ & $\mathrm{Cr}$ & $\mathrm{Zn}$ & $\mathrm{Al}$ \\
\hline $\mathrm{Wt} \%$ & 4.91 & 0.543 & 1.307 & 0.145 & 0.311 & 0.09 & 0.10 & Bal. \\
\hline
\end{tabular}

Age Hardening Heat Treatment : Age hardening or precipitation heat treatment included solution heat treatment and aging are made for aluminum base alloy of AA 2024-T3 and welded joints in electric furnace at temperature of $510^{\circ} \mathrm{C}$ for $30 \mathrm{~min}$. Quenching in water was followed by aging process at $190^{\circ} \mathrm{C}$ for 3hr. (ASM Handbook, 1991).

Samples Preparation for Microstructure: The samples made from a cross section of the FSW joints and base alloy were ground, polished and etched and observed under optical microscope in sequences steps. Wet grinding operation with water was done by using emery paper of $\mathrm{SiC}$ with the different grits of
$(220,320,500$, and 1000$)$. Polishing process was done to the samples by using diamond paste of size $(1 \mu \mathrm{m})$ with special polishing cloth and lubricant. They were cleaned with water and alcohol and dried with hot air. Etching process was done to the samples by using etching solution which is composed of $(99 \%$ $\mathrm{H}_{2} \mathrm{O}+1 \% \mathrm{HF}$ ). Then the samples were washed with water and alcohol and dried. The friction stir welded joint samples were examined by Nikon ME-600 optical microscope provided with a NIKON camera, DXM-1200F. The Vickers hardness instrument with a $300 \mathrm{gf}$ load was used for hardness profile across the friction stir weld joint. 


\section{Corrosion Tests}

Electrochemical Cell: Polarization resistance tests were used to obtain the corrosion rates. In the tests, cell current readings were taken during a short, slow sweep of the potential. The sweep was taken from (100 to +100$) \mathrm{mV}$ relative to (OCP). Scan rate defines the speed of the potential sweep in $\mathrm{mV} / \mathrm{sec}$. In this range the current density versus voltage curve is almost nearly linear. A linear data fitting of the standard model gives an estimate of the polarization resistance, which is used to calculate the corrosion current density $\left(I_{\text {corr }}\right)$ and corrosion rate. The tests were performed by using a WENKING Mlab multi channels potentiostat and SCI-Mlab corrosion measuring system from Bank Electroniks-Intelligent control $\mathrm{GmbH}$, Germany 2007, as shown in Figure 1 (David Enos ,1997). In this test, aluminum alloy (2024-T3) and FSW samples were used as working electrode (WE), a saturated calomel electrode immersed in the salt solution was used as reference electrode (RE), and a platinum electrode was used as auxiliary electrode (AE).

Samples Preparation for Corrosion: In addition to the steps, mentioned in section (Samples Preparation for Microstructure), additional one has been implemented; the samples were carefully plated with about $5 \mathrm{~mm}$ thickness and $25 \mathrm{~mm}$ wide to be fitted in special holder supplied with such apparatus as mentioned above. One $1 \mathrm{~cm}^{2}$ area of the weld joint which consists of weld nugget, thermo-mechanically affected zone (TMAZ) and (HAZ), and base metal were individually exposed to $3.5 \% \mathrm{NaCl}$ solution. The potentiodynamic scan was performed at scan rate of $(10 \mathrm{mV} / \mathrm{sec})$ by using potentiostat supported by corrosion measurement software.

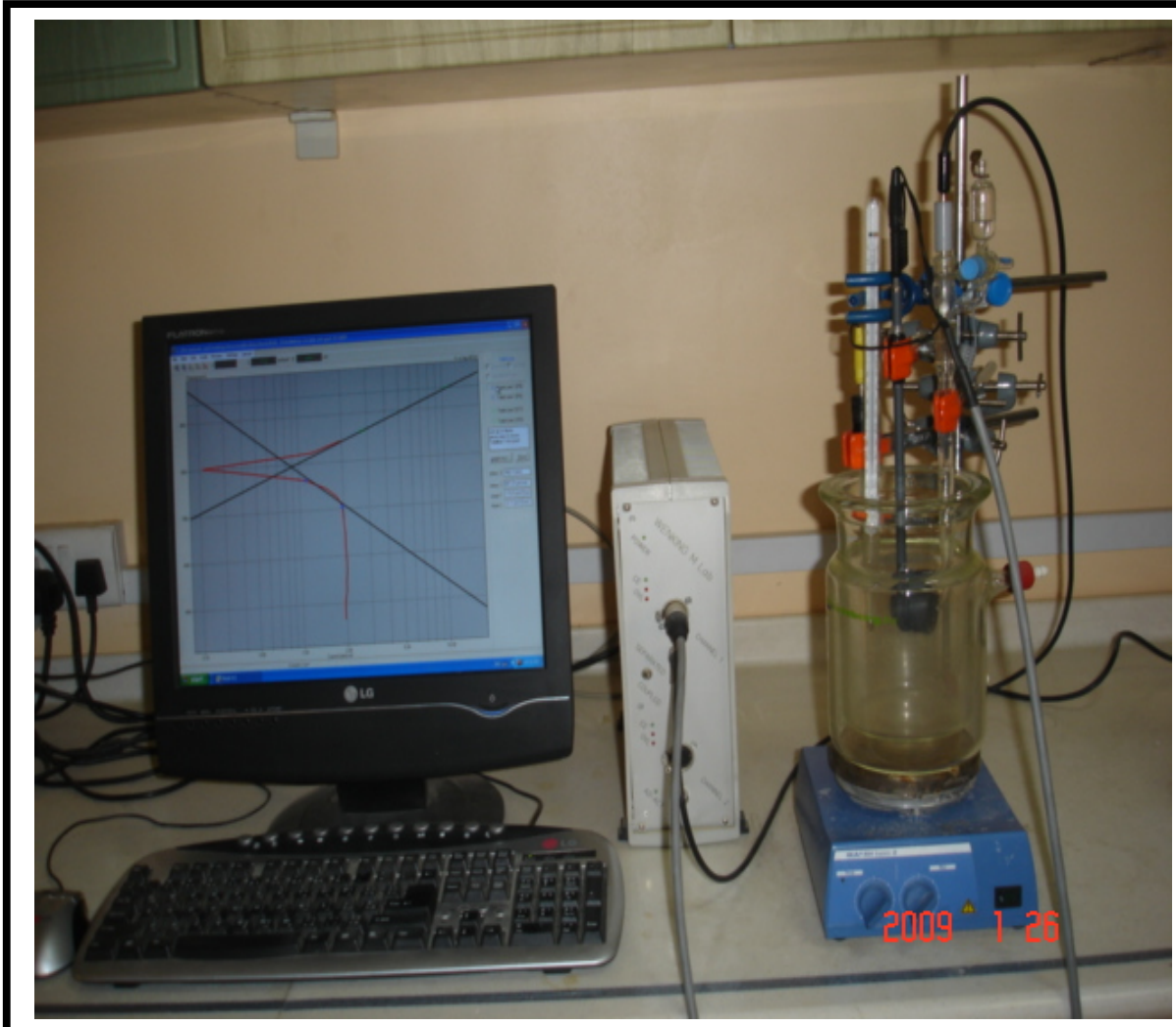

Fig 1 A photograph of the electrochemical corrosion unit (David Enos ,1997) 


\section{RESULTS AND DISCUSSION}

Micro structure Examinations: The microstructures resulting from friction stir welding (FSW) process in aluminum alloy AA2024-T3 (precipitation hardenable Al-alloy) are different from that of base metal microstructure or rolled structure. These changes can bring a difference in corrosion behavior of the weld. FSW is essentially a hot-working process where a large amount of deformation is induced into the workpiece through pin and shoulder and the

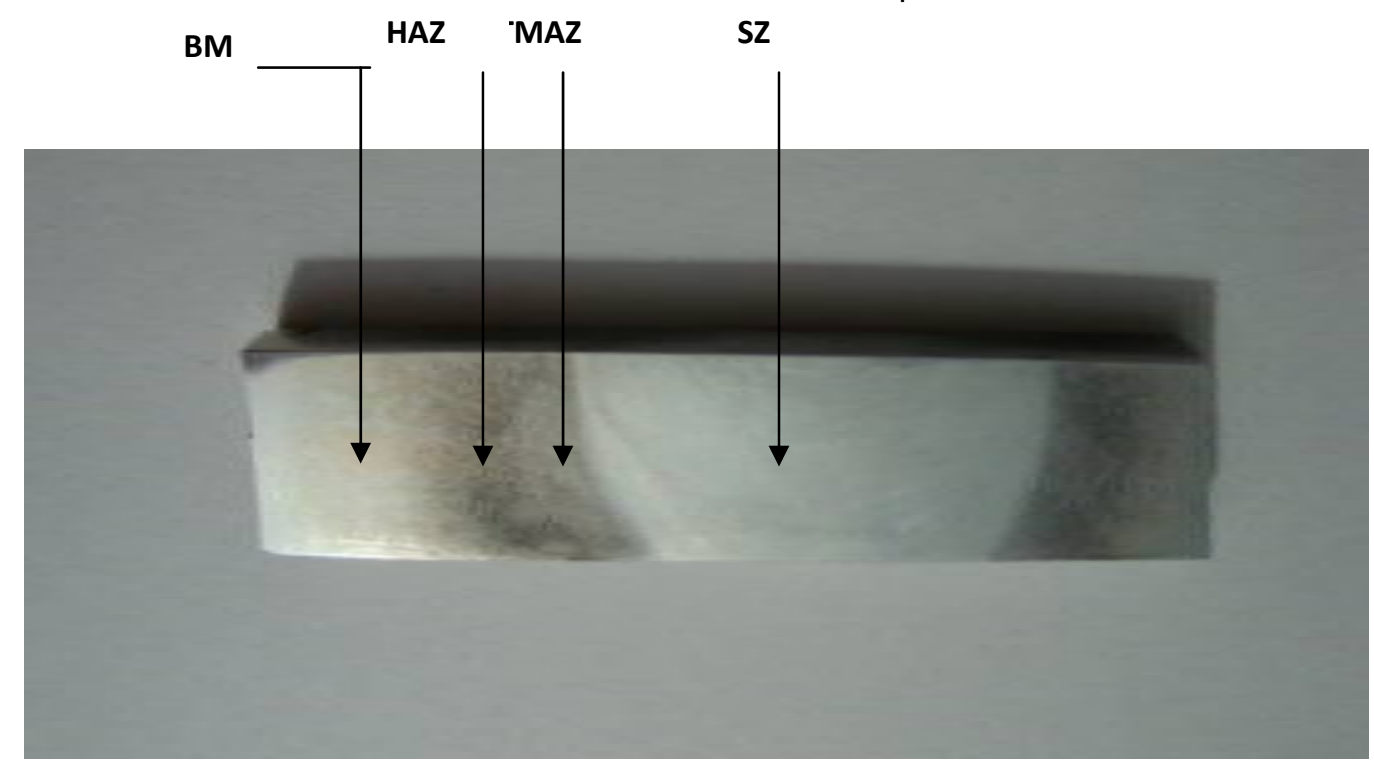

Fig 2 Photograph picture of the top surface of FSW joint showing the four zones of weld

Figure 3 shows the microstructures of the cross section area of welded joint before age hardening treatment .Figure 3-a shows the re-crystallized grain structure at the center position of the SZ. Figure 3-b consists of two different microstructures the first is a fine grain region on the left side resulting from the action of rotating probe .The second is an elongated microstructure on the right side remaining from base metal (BM). The transition region between the weld nugget and (TMAZ) is clearly observed as being microscopically sharp described as adjacent to the fully recrystallized nugget containing grains that exhibited varying degrees of recovery and recrystallization to give equaled grains with much smaller size compared to the large elongated grains of base metal (BM). Figures 3-c \& d show microstructures of heated affected zone (HAZ) and base metal $(\mathrm{BM})$ respectively. These microstructures results are similar to those of other researchers ( $\mathrm{Ju}$ Kang et al,2010 and Mohanad,2007). temperature never exceeds $0.8 \mathrm{Tm}$ (Cao and Kou,2005). The heat and deformation generated during FSW produce macrostructurally distinct regions across the weld as shown in Figure 2. FSW joint consists four zones as follows:

a- Stir zone (SZ) or nugget zone is fully recrystallized region at the weld center., b- Thermomechanically affected zone (TMAZ) is affected by heat and deformation, but is not re-crystallized, cHeat affected zone (HAZ) is affected only by heat, with no plastic deformation., d- Base metal (BM).

According to microstructural observation in this study ,the grain sizes in the weld nugget are significantly smaller than the parent metal and this can be attributed to the mechanical forces operative during welding which cause both refinement and re alignment of the matrix grains and should be beneficial with respect to various mechanical properties. This is due to the temperature difference between the tool shoulder side and base size and the tool centerline and the edge of the weld nugget which causes the grain size variations (Bradley and James, 2000).

Figure 4 shows the microstructures of the cross section joint after age hardening heat treatment which includes solution heat treatment at $510^{\circ} \mathrm{C}$ and aging at $190^{\circ} \mathrm{C}$ for $3 \mathrm{hrs}$. It is seen that, as expected, post weld solution treated and aging of the friction stir weld do not alter the grain structure in the stir zone. The fine grains in the weld zone in the as-welded 
condition are not stable during solution treatment, which results in undesirable coarsened grain structure. The overall microstructure is consistent with the observations of researchers Madhusudhan Reddy et al, 2006. They studied the microstructure of AA 6061 Al-alloy in the as-welded, post weld aging and post weld solution treatment conditions. Optical microscopy revealed that the elongated pancake microstructure of the base material is transformed into dynamically recrystalized microstructure of considerably smaller grain size in the weld nugget.

Hardness Profiles: Figure 5 shows hardness profiles of a transverse cross section of joints welded at a constant rotation speed and welding speed for as -weld and post weld solution treated and aged condition at $190^{\circ} \mathrm{C}$ for $3 \mathrm{hrs}$. The stir zone ( SZ) shows a great change in the hardness distribution from the weld center to HAZ and base metal. The miniumin hardness value in the HAZ is located on both advancing and retreating sides of weld. Soft zones on both sides of the HAZ could be caused by a coaresning and /or a dissolution of precipitates of $\mathrm{Al}_{2} \mathrm{CuMg}, \mathrm{Al}_{2} \mathrm{Cu}$ the strengthening phases into solution during welding. The hardness on one side of weld center is slightly higher than the other side. Hardening in the SZ could be due to the formation of GPZ at room temperature after welding. The observed hardness profiles were similar to those of other researchers (Madhusudhan Reddy et al, 2006 and Saad and Shibayanagi, 2007). After age heat treatment the hardness distribution shows a hardness drop in the HAZ, but the hardness values become higher for all zones of weld after solution and age treatments. This is due to the re-precipitation of the precipitates during age treatment.

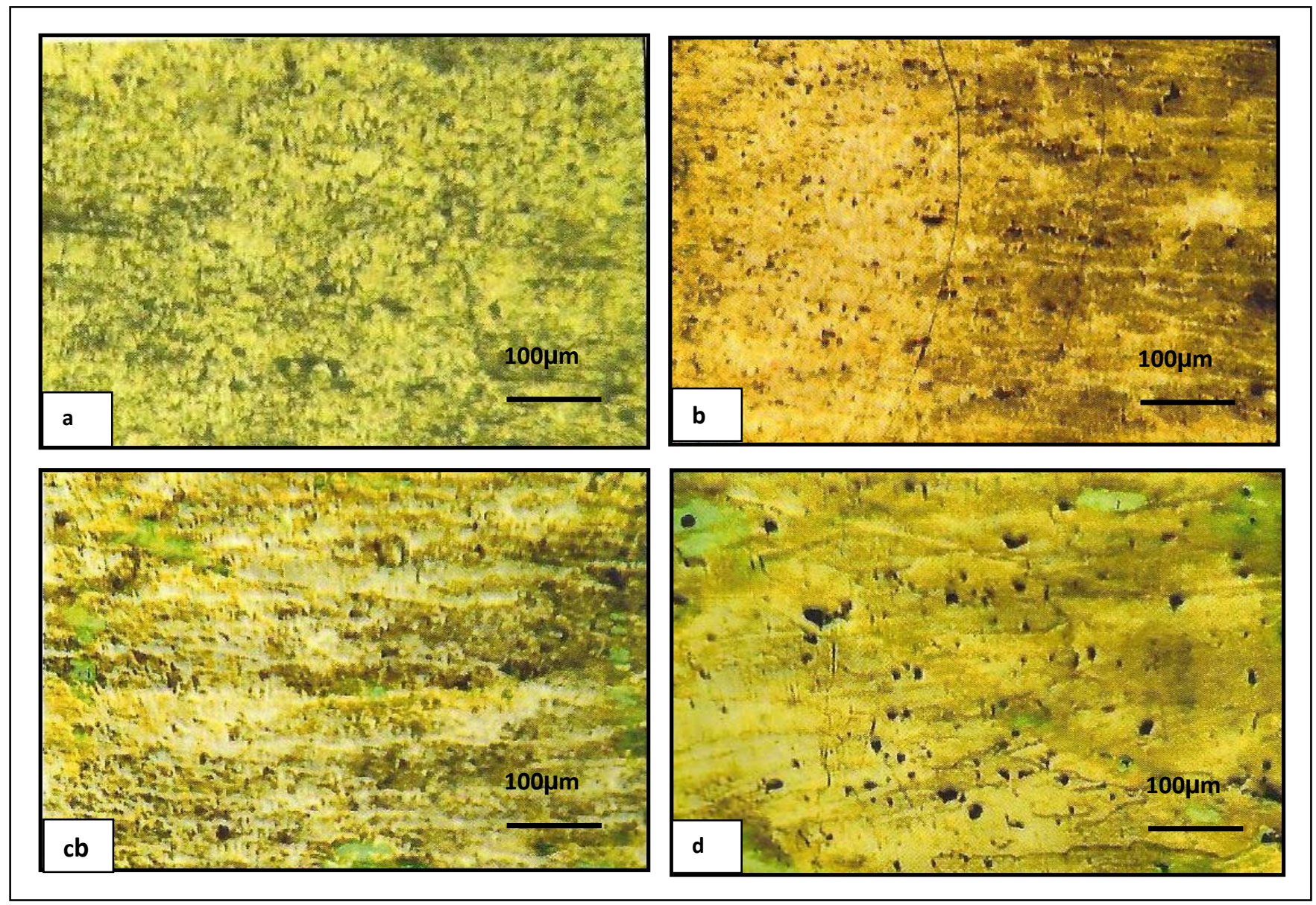

Fig 3 Microstructures of welded joint before age hardening heat treatment a- Stir zone (SZ) or nugget zone ,bThermo-mechanically affected zone (TMAZ) c- Heat affected zone (HAZ) d - Base metal (BM) 


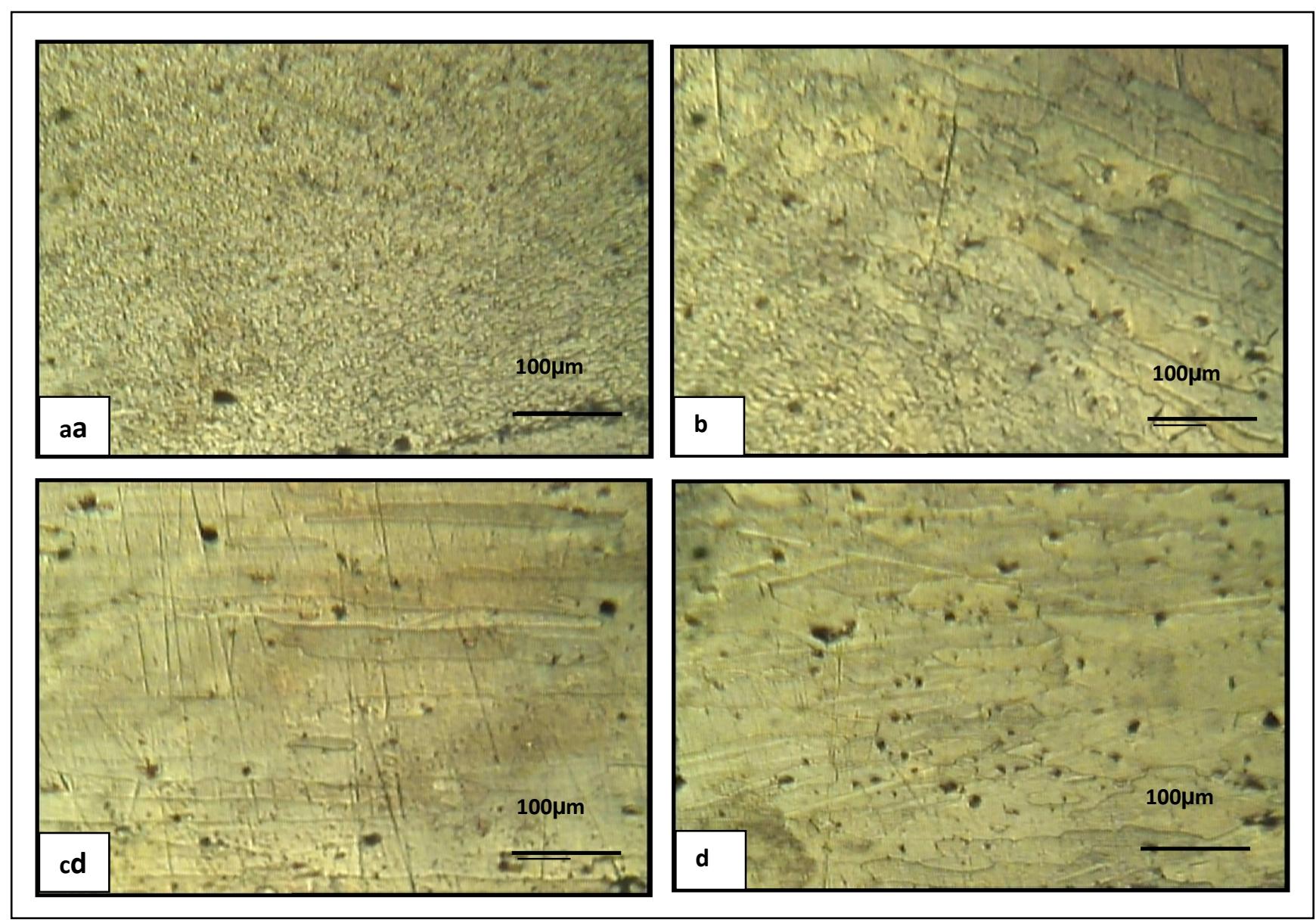

Fig 4 Microstructures of welded joint after age hardening heat treatment a- Stir zone (SZ) or nugget zone, bThermo-mechanically affected zone (TMAZ) c- Heat affected zone (HAZ) d - Base metal (BM)

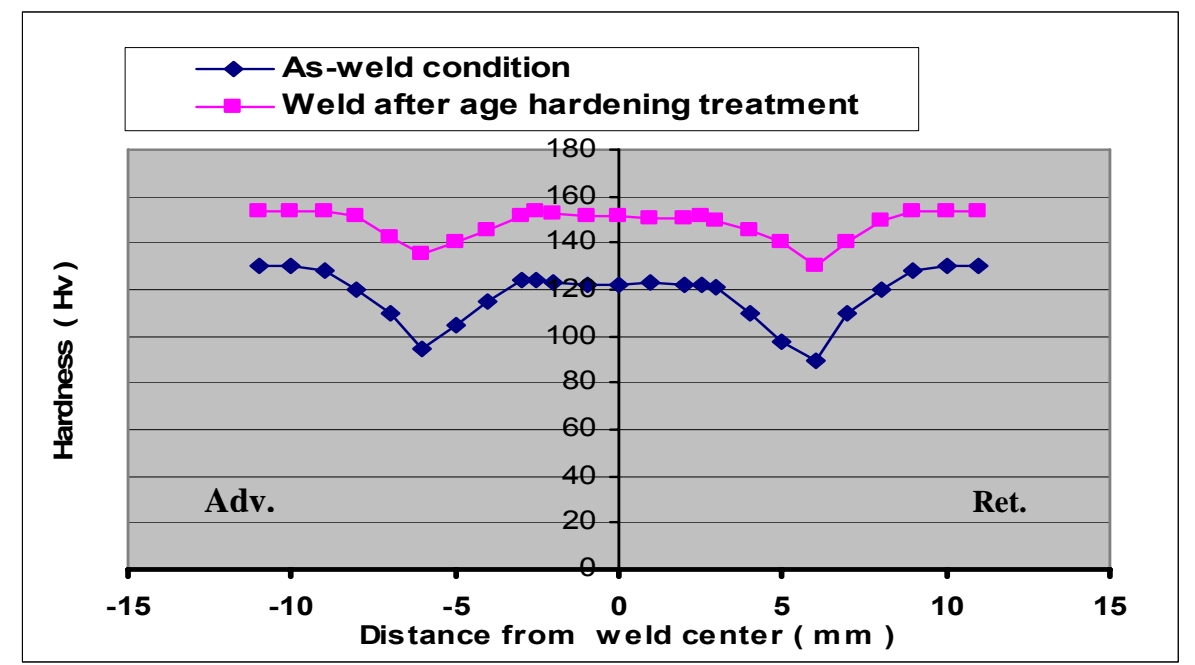

Fig 5 Hardness profiles of a transverse cross section of welds for as -weld condition and after age hardening heat treatment 
Corrosion Results

Potentiostatic Polarization Measurements Results : Generally a passive oxide film can be readily formed on the surface of aluminum alloys, when exposed to air or water. However the corrosion rate could be very high due to the presence of chloride ions (David Talbot and James Talbot, 1998 and Kenneth Trethewey and Chamberlain,1996). With an increase in the concentration of $\mathrm{Cl}$ - ,the pitting corrosion becomes severe and statistical maximum corrosion depth is consistent with Gumbel distribution for 2024-T3 aluminum alloy (Guo et al,2004). Further the corrosion behavior of Al-alloys largely depends on heterogeneity of their microstructures. The friction stir welding process induces dramatic changes in microstructures. In this study, electrochemical corrosion test by Tafel extrapolation method was carried out on all samples of base alloy of 2024-T3 and FSW in sodium chloride solution of $3.5 \% \mathrm{NaCl}$ to determine corrosion parameters, such as corrosion potential $\left(\mathrm{E}_{\text {corr }}\right)$ and corrosion current ( $\left.I_{\text {corr }}\right)$ as shown in Table 2.

Table 2 The results of corrosion tests of studied samples of aluminum alloy of AA2024-T3 in $3.5 \% \mathrm{NaCl}$ solution

\begin{tabular}{|c|c|c|c|}
\hline Sample & Heat treatment & Ecorr $(\mathrm{mV})$ & $\begin{array}{c}\text { Icorr } \\
\left(\mu \mathrm{A} / \mathrm{cm}^{2}\right)\end{array}$ \\
\hline $\begin{array}{c}\text { Base alloy } \\
2024-T 3\end{array}$ & As received & -650 \\
\hline $\begin{array}{c}\text { Base alloy } \\
2024-T 3\end{array}$ & $\begin{array}{l}\text { Solution heat treated } \\
510^{\circ} \mathrm{C}+\text { aging at } 190^{\circ} \mathrm{C} \text { for } 3 \mathrm{hrs}\end{array}$ & -556 & 15.68 \\
\hline Weld joint & As weld & -875 & 25.93 \\
\hline Weld joint & $\begin{array}{l}\text { Solution heat treated } \\
510^{\circ} \mathrm{C}+\text { aging at } 190^{\circ} \mathrm{C} \text { for } 3 \mathrm{hrs}\end{array}$ & -944 & 7.9 \\
\hline
\end{tabular}

Figures 6 and 7 show the polarization curves of the base alloy of 2024-T3 and FSW sample before and after age hardening heat treatment respectively in $3.5 \% \mathrm{NaCl}$ at temperature of $30^{\circ} \mathrm{C}$. It was shown that the corrosion behavior of base alloy significantly varies from that of welded joint, and the friction stir weld has higher corrosion current (or less corrosion resistance) than base alloy before age treatment. This is due to inhomogeneity of microstructure in weld regions or zones while the unwelded base alloy of 2024-T3 (in aging condition) has a uniform microstructure i.e. uniform distribution of precipitates in aluminum matrix. The precipitates are more noble and promote anodic dissolution of the matrix. After performing age or precipitation heat treatment for welded joint at $510^{\circ} \mathrm{C}$ and aging at $190^{\circ} \mathrm{C}$, it was noticed that corrosion current ( $\left.I_{\text {corr }}\right)$ is lower than that of base alloy. It has been shown that the welded joints are more negative corrosion potential ( $E_{\text {corr }}$ ) than the base alloy before and after age treatment. This is attributed to the residual stresses induced during friction stir welding. But the post weld age treatment leads to reduce the corrosion current and improve the corrosion resistance of weld because of precipitation homogeneity occurring in the microstructures of various welding regions. During FSW process only coarser precipitates could nucleate and grow but not finer ones. This aids in the formation of passive film, which remains more intact on surface of the sample and improves the corrosion resistance of the weld. These results are in agreement with those of other researchers (Venugopal et al,2004)]. Srinivasa Rao and Prasad Rao,2004 studied the mechanism of pitting corrosion of heat treatable $\mathrm{Al}-\mathrm{Cu}$ alloys and welds. Pitting corrosion involves three stages, pitting initiation, metastable pitting and pitting growth.

Boger,2003 reported that the aged samples are more susceptible to pitting corrosion than that of solution heat treated ones. He attributed these results to the weak passive film formed on $\mathrm{Al}_{2} \mathrm{CuMg}$ and $\mathrm{Al}_{2} \mathrm{Cu}$ the strengthening phases (precipitates) in the aged alloyed. The microstructures of pitted surfaces after potentiostatic polarization in the $3.5 \% \mathrm{NaCl}$ solution shown in Figure $8 a-b$ reveal clearly that pits density of weld joint is much more than that of base alloy. It can be found that mean diameter of pits which is calculated from Image Analyzer program for base alloy sample is lower than that of FSW sample before heat treatment. The mean pits are $39.03 \mu \mathrm{m}$ and $58.52 \mu \mathrm{m}$ for base alloy and FSW sample respectively. The poor pitting corrosion resistance of weld is due to difference in pitting potentials across the weld region or nugget and base alloy because of inhomogenity of microstructures in those regions. These results are confirmed by researchers Cao and 
Kou,2005. They observed that in most friction stir welds large $\theta\left(\mathrm{Al}_{2} \mathrm{Cu}\right)$ particles appeared to have formed during FSW process from agglomeration of fractured particles and the smaller ones of the $\theta$ ( $\mathrm{Al}_{2} \mathrm{Cu}$ ) particles in the work piece. These particles have solution potentials differing from that of the solid solution matrix in which they occur. Localized galvanic cell may be formed between them and the matrix.

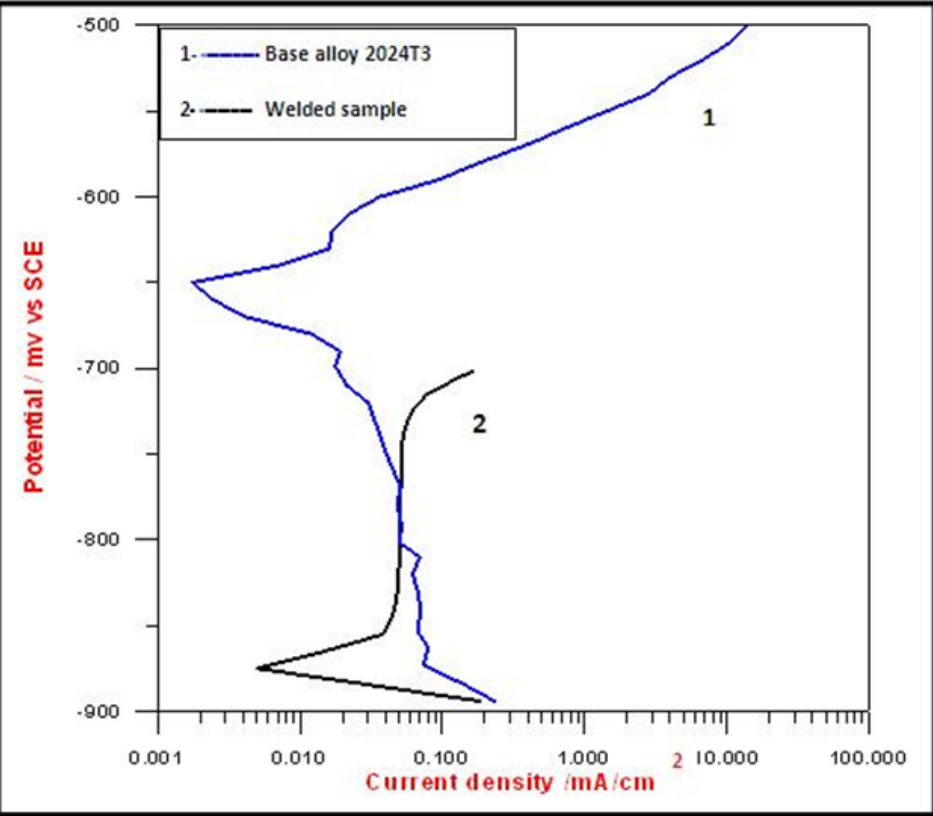

Fig 6 Polarization curves of the base alloy and friction stir weld before age hardening heat treatment in $3.5 \% \mathrm{NaCl}$ solution at temperature of $30^{\circ} \mathrm{C}$

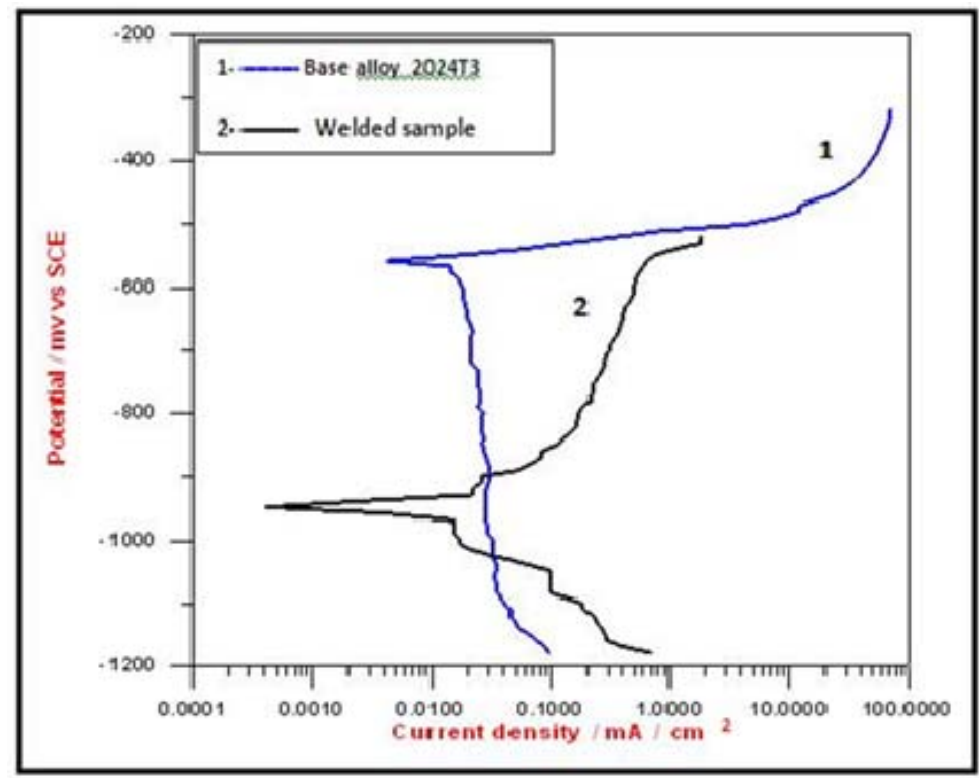

Fig 7 Polarization curves of the base alloy and friction stir weld after age hardening heat treatment in $3.5 \% \mathrm{NaCl}$ solution at temperature of $30^{\circ} \mathrm{C}$ 


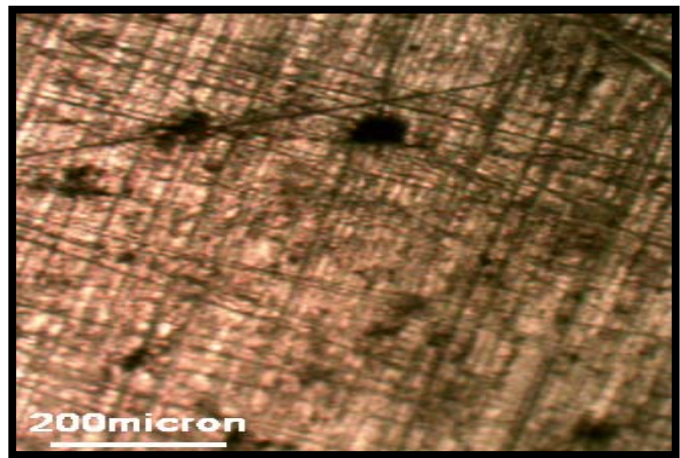

(a) Base alloy

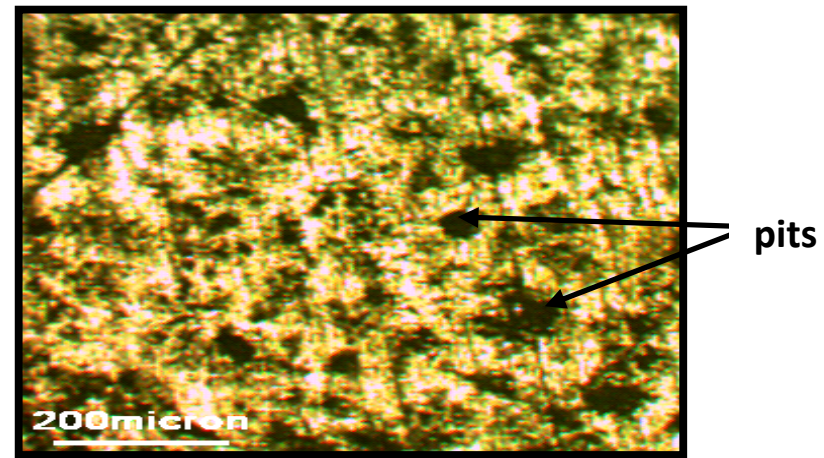

(b)FSW weld

Fig 8 Microstructures showing pits after electrochemical corrosion in $3.5 \% \mathrm{NaCl}$ solution

\section{CONCLUSIONS}

1- Grain refinement in stir weld zone has been achieved due to frictional heating and plastic flow.

\section{2- Age hardening heat treatment increases the} hardness values of welded joint because of homogeneity or uniform distribution of precipitates in aluminum matrix of friction stir weld zones.

3- The hardness profile across the weld is not consistent with grain size observed because the hardness after age treatment depends strongly on the precipitates distribution rather than on the grain size.

4- Corrosion resistance of base aluminum alloy of 2024-T3 in 3.5\% NaCl solution has been found better than that of friction stir weld before age hardening treatment.

5- Post-weld solution and aging treatment (age hardening) increase the corrosion resistance of the friction stir welded joint.

6- Corrosion potential $\left(\mathrm{E}_{\text {corr }}\right)$ of base alloy is more noble (less negative) than that of welded joint before and after heat treatment .

7- The weld samples were more susceptible to pitting corrosion than the base alloy of 2024-T3. Mean diameter of pits on base alloy is lower than that of welded joints.

\section{REFERENCES}

[1] Maria Posada, P. Jennifer Nguyen, R. David Forrest, J. Jobnnie Branch and Robert Denale, "Friction Stir Welding Advances Joining Technology", Special Issue AMPIAG, Quarterly Vol. 7, No.3 , p13-20, 2003.

[2] Sindo Kou, "Welding Metallurgy", $2^{\text {nd }}$ edition, John Wiley and Sons, Inc., 2003.

[3]http://www.esabna.com/us/en/education/knowledge/qa/ What-is-friction-stir-welding-of-aluminum.cfm.15-122008.

[4] M.A. Sutton, B. Yang, A.P. Reynolds, R. Taylor, " Microstructural Studies of Friction Stir Welds in 2024T3 Aluminum", Materials Science and Engineering, Vol. A323, p160-166,2002.

[5] Beate Heinz and Birgit Skroyzki ,"Characterization of a Friction Stir Welded Aluminum Alloy 6013", Metallurgical and Materials Transactions B, No.5,Vol 33, p 489, 2002.

[6] T. Venugopal, K. Srinivasa Rao and K. Prasad Rao ,"Studies on Friction Stir Welding AA7075 Aluminum Alloy", Trans. Indian Inst .Met ,Vol. 57 ,No.6, p 659663, 2004.

[7] G. Cao and S. Kou, "Friction Stir Welding of 2219 Aluminum Behavior of $\theta\left(\mathrm{Al}_{2} \mathrm{Cu}\right)$ Particles" ,Supplement of Welding Journal, January, p 1S-8S, 2005.

[8] C.S. Paglia and R.G. Buchheit," A Look in The Corrosion of Aluminum Alloy Friction Stir Welds", Scripta Materialia, Vol. 58, p 383-387, 2008.

[9] Weifeng Xu and Jinhe Liu," Microstructure and Pitting Corrosion of Friction Stir Welded Joints in 2219-O Aluminum Alloy Thick Plate", Corrosion Science ,Vol.51,p 2743-2751,2009. 
[10] Ju Kang, Rui-dong Fu, Guo-hong Luan , Chun-lin Dong and Miao $\mathrm{He}$ "In-Situ Investigation on The Pitting Corrosion Behavior of Friction Stir Welded Joint of AA2024-T3 Aluminum Alloy", Corrosion Science, Vol. 52, p 620-626, 2010.

[11] Zhili Feng, Sidney Diamond and Philip S. Sklad, " Friction Stir Processing of Advanced Materials", High Strength Weight Reduction Materials, Progress Report ,p101-107, 2003.

[12] ASM Handbook, Heat Treating, Vol. 4, 1991.

[13] G. David Enos, "The Potentiodynamic Polarization Scan", Technical Report 33, University of Virginia, 1997.

[14] O. Y. Mohanad, "Investigation of Mechanical and Microstructural Characteristics of Friction Stir Welded Joints", PhD Thesis, University of Baghdad, College of Engineering, 2007.

[15] G.R. Bradley and M.N. James, "Geometry and Microstructure of Metal Inert Gas and Friction Stir Welded Aluminum Alloy 5383-H321," Dept. of Mechanical and Marine Engineering, University of Plymouth, England, www.plymouth.ac.uk October 2000.

[16] G. Madhusudhan Reddy, P. Mastanaiah , C.V.S. Murthy , T. Mohandas and N. Viswanathan, "Microstructure, Residual Stress Distribution and Mechanical Properties of Friction-Stir AA 6061
Aluminum Alloy Weldments", Indian Society for NonDestructive Testing, Hyderabad Chapter, Proc. National Seminar on Non-Destructive Evaluation, Dec. $7-9,2006$.

[17] Saad Ahmed Khodir and Shibayanagi Toshya, "Microstructure and Mechanical Properties of Friction Stir Welding Similar and Dissimilar Joints of Al and Mg alloys", Transaction of JWRI ,Vo1 36, No.1, p 27-40, 2007.

[18] David Talbot and James Talbot, "Corrosion Science and Technology", CRC Press LLC, 1998. website at www.crepress.com .

[19] R. Kenneth Trethewey and J. Chamberlain, "Corrosion For Science and Engineering", $2^{\text {nd }}$ Edition, Longman Group Limited , 1996.

[20] M. Guo , D. Li , S.X. Rao , B.L. Guo,” Effect of Environmental Factors on The Corrosion of 2024-T3 Aluminum Alloy", Material Forum, Vol. 28, 2004, p 433438.

[21] K. Srinivasa Rao and K. Prasad Rao, "Pitting Corrosion of Heat Treatable Aluminum Alloys and Welds: A Review" ,Trans. Indian Inst. Met., Vol. 57, No.6, 2004, p.503-610.

[22] R. K. Boger, "Corrosion of Al-Cu Alloys Measured Using A Rotating Ring- Disk Electrodes", Dept. of Materials Science and Engineering, Ohio State University ,2003. 